Relations industrielles

Industrial Relations

\title{
Social Documents
}

Credit

Volume 7, numéro 3, juin 1952

URI : https://id.erudit.org/iderudit/1023064ar

DOI : https://doi.org/10.7202/1023064ar

Aller au sommaire du numéro

Éditeur(s)

Département des relations industrielles de l’Université Laval

ISSN

0034-379X (imprimé)

1703-8138 (numérique)

Découvrir la revue

Citer ce document

(1952). Social Documents : Credit. Relations industrielles / Industrial Relations, 7(3), 256-258. https://doi.org/10.7202/1023064ar

\section{Résumé de l'article}

The following text is an English translation by the National Catholic Welfare Conference of the discourse given in the French language by His Holiness Pope Pius XII on October 24, 1951, to delegates from 46 nations attending the International Congress on Credit Questions. In his discourse, the Pontiff discussed the moral and social importance of credit and encouraged its fruitful extension.
Tous droits réservés @ Département des relations industrielles de l’Université Laval, 1952
Ce document est protégé par la loi sur le droit d'auteur. L'utilisation des services d'Érudit (y compris la reproduction) est assujettie à sa politique d'utilisation que vous pouvez consulter en ligne.

https://apropos.erudit.org/fr/usagers/politique-dutilisation/ 
qogether and try to work out something that is practicable, in an atmosphere which has been poisoned by the preposterous nonsense they have been talking at each other for months.

The editorial concludes in this way: This kind of thing is becoming increasingly common. It is not healthy. It does nobody anygood. It is positively dangerous at a time when one of the most imperative needs is that everyone should understand as fully as possible just what are the limits within each bargaining can take place without disastrous effects on society as a whole. When responsibility, reason, tolerance and understanding are essential if western democratic society is to survive, let alone advance, the Conciliation Board puts a premium on irresponsibility, unreason, intolerance and ignorance.

What is the alternative? To let the parties slug it out, without public intervention of any kind? No, to provide a large enough body of expert, full-time Conciliation Officers, and leave the rest to straight collective bargaining, strikes and all, with only such further "ad hoc" intervention by public authority as the national health and safety may demand, it may sound risky, but it isn't, it will encourage both parties to act like grown-up men, instead of spoiled children. In the long run, that will mean fewer strikes, better industrial relations, and a more genuinely democratic society.

\title{
SOCIAL DOCUMENTS
}

\section{CREDIT}

\author{
s. \\ The following text is an English translation by the National Catholic \\ Welfare Conference of the discourse given in the French language \\ by His Holiness Pope Pius XII on October 24, 1951, to delegates from \\ 46 nations attending the International Congress on Credit Questions. \\ In his discourse, the Pontiff discussed the moral and social importance \\ of credit and encouraged its fruitful extension.
}

Your conduct of which We are well aware, Gentlemen, is a convincing proot of the lofty conception you have of your profession and your role. Above intelligent handling of funds, above even the mere financial interest of your banks and their clients, you place moral and social utility. You mark the border or, to be more exact, the crossroads where capital, imagination, and labor encounter each other.

When those who fish in troubled waters stress and exaggerate opposition, (between capital, imagination and labor) your task consists in putting them in touch with one another, in making them useful one to the other. Especially in what concerns credit, the chief object of your International Congress, you are councillors more than executives or agents of banking operations.

\section{Proper use of funds}

How much capital is lost through waste and luxury through selfish and dull enjoyment, or accumulates and lies dormant without being turned to profit! There will always be egoists and selfseekers; there will always be misers and those who are short-sightedly timid. Their number could be considerably reduced if one would interest those who have money in using their funds wisely and profitably, he they great or small. It is largely due to this lack of interest that money lies dormant. You can remedy this to a great extent by making ordinary depositors collaborators, either as bond or share-holders, in undertakings whose launching and thriving would be of great benefit to the community, such as industrial activities, agricultural production, public works, or the construction of houses for workers, ducational or cultural institutions, welfare or social service. 
Boards of directors have been greatly criticized. Such criticism is justifiable insofar as the members of these boards envisage nothing but excessive increase of dividends. If, on the contrary, they have at heart the wise and healthy handling of capital, then by doing this alone they are performing a social activity of. the first order. They are assuming an intense moral and psychological task that is much different from the simple impersonal transactions at the desk or cotmter. Who knows, perhaps one day for such transactions, some inventor will so perfect adding machines, these mechanical or electric brains, that the client will have nothing to do but press a button in order to carry out all the business that brings him to the bank. But what machine, however ingenious, what system, however smart, can ever take the place of the banker, the manager of a house of credit, who studies the client, explains to him and makes him aware of what may interest him in order to direct his cooperation, enabling him to follow intelligently the fortunes of the undertaking he supports? Does this not constitute a social and moral activity of the greatest' value, an activity that brings the most fruitful results?

In spite of everything, the investor wants an assurance that he will not lose the money he has subscribed. Without risking the honest return due on his investment, he also desires to make it a source of benefit for others and for society. This supposes, of course, that the undertaking merits his participation and that it is, essentially, of a nature to interest him because of its being in harmony with his personal disposition and taste. Here, then, is another aspect of your role.

\section{NECESSITY OF CAREFULLY DIRECTING THOSE SEEKING CREDIT}

A young inventor, a man with initiative, a benefactor of humanity comes to you for a loan. You must study him in order not to put the trusting lender into the hands of a utopian or crook, in order to avoid the risk of sending away a deserving borrower capable of giving immense services but merely lacking the necessary funds for carrying them out. You must weigh his worth, understand his projects and plans, help him if needs be with counsels and suggestions to preverit his acting imprudently, to make his idea more practical, to find out to whom to send and recommend him for a loan.

How many geniuses, how many intelligent, generous, and active men die in misery, discouraged, survived only by their ideas - ideas which men more clever than they will exploit for their own profit? And then, there are all those people put into temporary difficulties through a bad year, a poor harvest, Iosses caused by war or revolution, sickness, or some other unforeseen and unforeseenable circumstance in which they are not at fault. Through a loan such men could rise again, set about working, and, in time, pay off their debt. What material help, what moral comfort you could give to all these!

\section{REsults of THE MEeTing OF CAPITAL AND IDEAS}

After what We have said, it seems superflous to speak of the immediate result of the meeting of capital and ideas. In proportion to the importance of the capital and the practical value of the idea, the labor crisis will be more or less slowed up. The conscientious and hardworking laborer will find employment more easily; the growth of production will progressively, though perhaps slowly, lead toward an economic balance; the many inconveniences and disorders, deplorably resulting from strikes, will be lessened for the greater good of a healthy domestic, social, and moral life. To a certain degree, however modest, the saving of money will become possible for a greater number of people, bringing with it all the many various advantages of which We spoke in an address on this subject on December 3, 1950.

The proud knowledge of partaking in so great a work of reconstruction must be an encouragement to you in the midst of your difficulties, worries and even opposition which, especially in times such as the present, cannot be lacking. 
As for Us, gentlemen, We express Our deep appreciation of your work and the spirit directing it. And from Our whole heart We ask God to shower His graces on your labors, yourselves, and your families. *

* Headings are the Editor's.

\title{
OCCUPATIONAL CORPORATIVE ORDER
}

\begin{abstract}
The following text is an English translation by the National Catholic Welfare Conference of the address pronounced in January 31 th 1952 by His Holiness Pope Pius XII to the Italian Catholic Association of Employers in which he asked for the Christian spirit as the basis for the social order and criticized forced co-determination.
\end{abstract}

We thank you wholeheartedly, beloved sons, and We are proud of you. With no less modesty than zeal you dedicate yourselves to a task which We consider of great importance. A lofty ideal, and one worthy of you, has been its inspiration. This undertaking is still young. Nevertheless, during the first five years of its life, it has already produced good results and augurs better and more abundant ones. The promise it holds is guaranteed more by the object of the undertaking and the divine aid it invokes than by the powerful support of men.

Zeal has made you begin your task without waiting until you were many in number or equipped with all the means that might have been desired. Modesty has allowed you to advance prudently, sure of your step, without planning on a grand scale or working out minute details, but with the clarity and precision of thought which animates you.

\section{Chrustian Concept of Business}

What then is it that you believe? What is this ideal which daily becomes clearer and more enlightening? To Us it seems the clear lofty and Christian concept you have of business. For you it is more than a mere means of earning a livelihood and maintaining the lawful dignity of your position, your individual independence and that of your families. It is more than the technical and practical collaboration of ideas, capital and many types of labor which favors production and progress. It is more than an important factor of economic life, more than a simple - and very praiseworthy - contribution to the carrying out of social justice.

If it were just this, it would be insufficient to establish and promote the complete order because there is no order but the one which rules the whole of life and all activities, material, economic, social and especially Christian, without which man remains always incomplete.

\section{A Comnton Action}

Without doubt, you have not pretended - that would have been a dream, although a happy one - to bring about this order in a single stroke or even to have outlined its definitive program. We are certain that you have not attempted to do this. But your purpose is clearly determined, and you have no hesitation in this. That is at the heart of the matter. It has taken possession of your minds. You are determined to do your best to follow it, although aware that you can achieve it only step by step in the light of experience.

There is no doubt that you have already obtained results, even though they are nothing more than your meeting, your agreement, your common action and 